\title{
Three New Complexes of Platinum(II) with Doxycycline, Oxytetracycline and Chlortetracycline and their Antimicrobial Activity
}

\author{
Wendell Guerra, ${ }^{a}$ Iara R. Silva, ${ }^{a}$ Elaine A. Azevedo, ${ }^{a}$ Ana R. de S. Monteiro, ${ }^{b}$ Mônica \\ Bucciarelli-Rodriguez, ${ }^{b}$ Edmar Chartone-Souza, ${ }^{b}$ Josianne N. Silveira, ${ }^{c}$ Ana P. S. Fontes ${ }^{d}$ and \\ Elene C. Pereira-Maia ${ }^{*, a}$
}

\author{
${ }^{a}$ Departamento de Química, ICEx, ${ }^{b}$ Departamento de Biologia Geral, ICB and \\ ${ }^{c}$ Departamento de Análises Clínicas e Toxicológicas, FF, \\ Universidade Federal de Minas Gerais, 31270-901 Belo Horizonte - MG, Brazil \\ ${ }^{d}$ Departamento de Química - ICE, Universidade Federal de Juiz de Fora 36036-330, Juiz de Fora MG, Brazil.
}

\begin{abstract}
Este artigo descreve a síntese e a caracterização de três novos complexos de platina(II) com a oxitetraciclina, doxiciclina e clortetraciclina por análise elementar, espectroscopias IV e RMN de ${ }^{195} \mathrm{Pt}$. As interações da doxiciclina com íons $\mathrm{Pt}^{\mathrm{II}}$ em função do $\mathrm{pH}$ foram estudadas por RMN de ${ }^{1} \mathrm{H}$. Todas as tetraciclinas investigadas formam complexos 1:1 com a $\mathrm{Pt}^{\mathrm{II}}$ via oxigênio do grupo hidroxila e oxigênio do grupo amida do anel A. As concentrações mínimas inibitórias (MIC) dos ligantes e de seus complexos de $\mathrm{Pt}^{\mathrm{II}}$ foram determinadas em duas cepas sensíveis $(E$. coli HB 101 and E. coli ATCC 25922) e em uma resistente (E. coli HB101/pBR322). O complexo de platina da doxiciclina é duas vezes mais potente do que o antibiótico livre na cepa resistente. Os coeficientes de partição dos complexos em octanol e água foram determinados. O aumento da lipofilia causa um aumento da atividade antimicrobiana na cepa resistente.
\end{abstract}

This paper reports on the synthesis and characterization of three new platinum(II) complexes with oxytetracycline, doxycycline and chlortetracycline by elemental analysis, IR and ${ }^{195} \mathrm{Pt}$ $\mathrm{RMN}$ spectroscopies. Doxycycline interactions with $\mathrm{Pt}^{\mathrm{II}}$ ions as a function of the $\mathrm{pH}$ were studied by ${ }^{1} \mathrm{H}$ NMR. All the investigated tetracyclines form 1:1 complexes with $\mathrm{Pt}^{\mathrm{II}}$ via the oxygen of the hydroxyl group and oxygen of the amide group at ring A. The minimal inhibitory concentrations (MIC) of the ligands and those of their $\mathrm{Pt}^{\mathrm{II}}$ compounds were determined in two sensitive strains (E. coli HB 101 and E. coli ATCC 25922) and in a resistant one (E. coli HB101/ pBR322). Platinum complex of doxycycline is twice as potent as the free antibiotic in the resistant strain. Octanol/water partition coefficients of the complexes were determined. Increasing lipophilicity enhances antimicrobial activity in the resistant strain.

Keywords: tetracycline derivatives, platinum complexes, antimicrobial activity, bacterial resistance

\section{Introduction}

Tetracyclines $(\mathrm{Tc})$ were the first antimicrobial group of drugs for which the term "broad-spectrum" was used, i.e., an effective drug against a large variety of bacteria, including both Gram-positive and Gram-negative. ${ }^{1}$ The main mechanism of tetracycline action is the inhibition of protein synthesis. The strong binding of a magnesium complex of tetracycline, $[\mathrm{MgTc}]^{+}$, to the bacterial $30 \mathrm{~S}$ ribosomal subunit leads to the inhibition of protein synthesis by causing the rupture of codon-anticodon interactions between tRNA and mRNA and consequent

*e-mail: elene@qui.ufmg.br interruption of the bond between the aminoacyl-tRNA and the ribosomal acceptor site..$^{1,2}$ The pharmacokinetics and bioavailability of tetracyclines are affected by metal coordination. In blood plasma, the drug is transported as calcium complexes. ${ }^{3}$ In the intracellular medium, magnesium complexes seem to be more important as they probably play a role in binding to ribosomes. ${ }^{4}$

The clinical use of tetracycline and analogues in the treatment of bacterial infections has declined because of the emergence of bacterial resistance to these drugs. Almost all pathogenic bacteria have acquired resistance against the presently known and used antibiotics. Resistance mechanisms against tetracycline involve proteins that either protect the ribosome from $[\mathrm{MgTc}]^{+}$, 
or export $[\mathrm{MgTc}]^{+}$out of the bacterial cell. In order to enter the cell and bind to the ribosome, Tc must cross the cytoplasmic membrane. A membrane-associated protein, (Tet $A(B)$ ), that mediates an active efflux of tetracycline has been identified in the cytoplasmic membrane of resistant bacteria..$^{5-7}$ This protein acts as an antiporter by coupling the efflux of $[\mathrm{MgTc}]^{+}$with the influx of a proton, thereby preventing the attack of $[\mathrm{MgTc}]^{+}$at the ribosome.

The expression of Tet $A(B)$ is tightly regulated by a repressor molecule, the tetracycline repressor. In the absence of tetracycline it is repressed because the resistance protein is toxic to the cell, as it interferes with the maintenance of the electrostatic potential across the cell membrane. In the absence of $[\mathrm{MgTc}]^{+}$, the repressor is bound to the operator gene. This process switches it off and blocks the transcription of the structural gene that encodes for the resistance protein Tet $\mathrm{A}(\mathrm{B})$. If $[\mathrm{MgTc}]^{+}$is present, this complex binds to the tetracycline repressor, inducing conformational changes in it that weaken its affinity towards the operator gene. As a consequence, the operator gene is released and Tet A(B) is expressed. ${ }^{8}$

Many efforts have been made to control the propagation of multidrug resistance strains worldwide. ${ }^{5-12}$ In a previous work, we described the syntheses of platinum(II) and palladium(II) tetracycline complexes. The former is six times and the later sixteen times as potent as tetracycline in inhibiting the growth of a resistant bacteria strain. ${ }^{11,12}$

Besides the pharmacological importance of tetracyclines, these molecules possess an interesting structure with many potential metal-binding sites: oxygens at the $C_{10}-C_{12}$ phenolic $\beta$-diketone system, enolic oxygens and the nitrogens at $\mathrm{C} 4$ and at the carboxamide group in ring $\mathrm{A}$.

In this work, we report a study of platinum(II) interactions with doxycycline (Dox), oxytetracycline (Oxy), and chlortetracycline (Chl) and their antimicrobial activity in three E. coli strains.

\section{Experimental}

\section{Reagents}

Oxytetracycline hydrochloride (Oxy), doxycycline hydrochloride (Dox) and chlortetracycline hydrochloride (Chl) were purchased from Sigma Co. Stock solutions were prepared just before use to avoid ligand degradation caused by oxygen and light. Potassium tetrachloroplatinate is commercially available (from Sigma Co).

\section{Synthesis of the complexes}

All the complexes were synthesized following the same general procedure and we describe below only the synthesis of the $\mathrm{Pt}^{\mathrm{II}}$ complex of doxycycline. $\mathrm{K}_{2} \mathrm{PtCl}_{4}$ $(0.2075 \mathrm{~g}, 0.5 \mathrm{mmol})$ was added to $5 \mathrm{~mL}$ of an aqueous solution of doxycycline $(0.5 \mathrm{mmol})$ and the mixture was stirred for $120 \mathrm{~min}$. The solid formed was separated by filtration, washed with water, and dried under vacuum.

[Pt(Oxy)Cl $]$ ] $2 \mathrm{H}_{2} \mathrm{O}(\mathbf{1}) . \mathrm{IR}(\mathrm{KBr}) \mathrm{v}_{\max } / \mathrm{cm}^{-1}: 3411,3097$, $1668,1618,1584,1541,1458,1371,1308,1239,1212$, $1171,1134,1048,1010,914,879,844,772,725,675$, 609, 595, 570, 544, 516, 320, 311. ${ }^{195} \mathrm{Pt}$ NMR (86 MHz; DMF-d $\left.{ }_{7}\right) \delta-1462.8$. Yield: $346.1 \mathrm{mg}, 91 \%$. Anal. Calc. for $\left[\mathrm{Pt} \mathrm{Cl}_{2}\left(\mathrm{C}_{22} \mathrm{H}_{24} \mathrm{O}_{9} \mathrm{~N}_{2}\right)\right] .2 \mathrm{H}_{2} \mathrm{O}: \mathrm{C}, 34.63 ; \mathrm{H}, 3.67 ; \mathrm{N}$, 3.67; Pt 25.57. Found: C, 34.06; H, 3.66; N, 3.52; Pt $25.11 \%$. Color: Pale yellow.

[Pt(Dox) $\left.\mathrm{Cl}_{2}\right] \cdot 2 \mathrm{H}_{2} \mathrm{O}$ (2). IR(KBr) $v_{\max } / \mathrm{cm}^{-1}: 3412,3200$, 2929, 1664, 1618, 1578,1457, 1324,1243, 1216, 1170, 1128, 1042, 1039, 1005, 987, 884, 803, 770, 663, 617, $587,550,515,316,307 .{ }^{195} \mathrm{Pt}$ NMR (86 MHz; DMF- $\left.d_{7}\right)$ $\delta-1469.5$. Yield: $320.04 \mathrm{mg}, 84 \%$. Anal. Calc. for $\left[\mathrm{PtCl}_{2}\left(\mathrm{C}_{22} \mathrm{H}_{24} \mathrm{O}_{8} \mathrm{~N}_{2}\right)\right] .2 \mathrm{H}_{2} \mathrm{O}: \mathrm{C}, 35.36 ; \mathrm{H}, 3.75 ; \mathrm{N}, 3.75$ Pt, 26.12\%. Found: C, 35.62; H, 3.71; N, 3.79; Pt, 25.61\%. Color: Pale yellow.

$\left[\mathrm{Pt}(\mathrm{Chl}) \mathrm{Cl}_{2}\right] \cdot 2 \mathrm{H}_{2} \mathrm{O}$ (3). IR(KBr) v $v_{\max } / \mathrm{cm}^{-1}: 3403$, 3070,1660, 1618, 1578,1542, 1497, 1447, 1353, 1311, 1239, 1223, 1202, 1123,1042, 1006, 944, 837, 798, 695, 591, 541, 515, 494, 320, 315. ${ }^{195} \mathrm{Pt}$ NMR (86 MHz; DMF- $\left.d_{7}\right) \delta-1464.3$. Yield: $159.31 \mathrm{mg}, 39 \%$. Anal. Calc. for $\left[\mathrm{Pt} \mathrm{Cl}_{2}\left(\mathrm{C}_{22} \mathrm{H}_{24} \mathrm{O}_{8} \mathrm{~N}_{2} \mathrm{Cl}\right)\right] .2 \mathrm{H}_{2} \mathrm{O}: \mathrm{C}, 33.82 ; \mathrm{H}, 3.45 ; \mathrm{N}$, 3.58; Pt, 24.98\%. Found: C, 34.40; H, 3.99; N, 4.03; Pt 24.51. Color: Yellow.

\section{Spectroscopic measurements}

Infrared spectra were recorded over the $400-4000 \mathrm{~cm}^{-1}$ region with a Perkin Elmer 283 B spectrometer. The samples were examined in $\mathrm{KBr}$ pellets.

${ }^{1} \mathrm{H}$ NMR spectra were obtained using a Bruker Avance DRX 400 spectrometer in $\mathrm{D}_{2} \mathrm{O}$ at $\mathrm{pH} 3.0,5.0,7.0$ and 8.0 with tetramethylsilane as an internal standard. The ligand concentration used was $5.0 \times 10^{-3} \mathrm{~mol} \mathrm{~L}^{-1}$ and, when indicated, that of $\mathrm{Pt}^{\mathrm{II}}$ was $1 \times 10^{-2} \mathrm{~mol} \mathrm{~L}^{-1}$.

${ }^{195} \mathrm{Pt}$ NMR (86 MHz) spectra were obtained using a Bruker Avance DRX 400 spectrometer in DMF- $d_{7}$ with $\mathrm{K}_{2} \mathrm{PtCl}_{4}$ as the internal standard. 


\section{Conductivity measurements}

Conductivity studies were carried out with a Digimed DM 31 conductivity meter using a cell of constant 1.013 $\mathrm{cm}^{-1}$, spectroscopic grade dimethylformamide (Merck) $\left(\Lambda_{\mathrm{M}}=1.22 \mu \mathrm{S} \mathrm{cm}^{-1}\right)$ and tetraethylammonium bromide $\left(\Lambda_{\mathrm{M}}=79.56 \mu \mathrm{S} \mathrm{cm}^{-1}\right)$ as a standard.

\section{Elemental analysis}

Carbon, nitrogen and hydrogen were determined on a Perkin Elmer 2400 CHN. Atomic absorption analysis of the platinum content was carried out on a model 8200 Hitachi Atomic Absorption Spectrophotometer.

\section{Partition coefficient}

Partition coefficients for the platinum complexes were determined in duplicate in an $n$-octanol/water system. Each platinum complex was dissolved in water at $2 \times 10^{-5} \mathrm{~mol} \mathrm{~L}^{-1}$ and subsequently an equal volume of $n$-octanol was added. The mixtures were shaken mechanically for $24 \mathrm{~h}$ to insure the distribution between the two solvent phases. The samples were centrifuged (13000 rpm, $5 \mathrm{~min}$ ). Afterwards they were diluted 5-fold and the platinum concentration was determined in both phases by FAAS in a Varian model Zeeman 220 spectrophotometer equipped with a graphite tube atomizer and an autosampler. Results are expressed as apparent partition coefficients (P) done by the total platinum in $n$-octanol divided by the total platinum in the aqueous layer. ${ }^{13}$

Microbial strains, plasmids and growth conditions

The sensitive and resistant bacterial strains selected from the bacteria collection of the Laboratory of Microbial Molecular Genetics of the General Biology Department of ICB-UFMG to perform microbiological tests were: E.coli $\mathrm{HB} 101 \mathrm{~F}-$ hsdS $20\left(\mathrm{r}_{\mathrm{B}}^{-}, \mathrm{m}_{\mathrm{B}}{ }^{-}\right)$leuB6 supE44 ara 14 recA13 proA2 rpsL20 (str') lacY1 galK2 mtl.$^{14}$

E.coli HB101/pBR322 is an E.coli HB101 harboring plasmid pBR322 that carries resistance genes to ampicillin (Ap) and tetracycline (Tc). It is a cloning vector derivative of pSC101. ${ }^{15}$

E. coli ATCC 25922: clinical isolate, susceptible to cefamandole, cephalexin, cephaloglycin, cephaloridine, cephalothin, chloramphenicol, colistin [colimycin], gentamicins, kanamycin, nalidixic acid, neomycin, tetracycline (collection ATCC).
Bacterial cultures were grown in the specified medium at $37{ }^{\circ} \mathrm{C}$. Culture stocks were performed on Lignières medium $(0.8 \% \mathrm{~m} / \mathrm{v}$ Difco Nutrient Broth, $0.5 \% \mathrm{~m} / \mathrm{v}$ Sigma gelatin, $0.7 \% \mathrm{~m} / \mathrm{v}$ Merck agar).

\section{Determination of Minimal Inhibitory Concentration}

Tetracyclines and their complexes were dissolved in $\mathrm{N}, \mathrm{N}$-dimethylformamide. Stock solutions were diluted accordingly and added to Mueller Hinton Agar (Merck) previously melted and cooled to $40{ }^{\circ} \mathrm{C}$ for the preparation of plates. This agar was distributed onto Petri dishes so as to obtain antibiotic concentrations of $2.08,4.16,8.32$, 16.60, 33.30, 66.50, 133.00, and $266.20 \mu \mathrm{mol} \mathrm{L}^{-1}$. Dimethylformamide concentration did not exceed $2.7 \%$. Plates for each concentration were prepared in duplicate. Control plates containing only the solvent (dimethylformamide), the metal salt $\left(\mathrm{K}_{2} \mathrm{PtCl}_{4}\right)$, or Nutrient Agar without either drug or solvent were also prepared.

The bacterial strains selected were transferred to 4.0 $\mathrm{mL}$ of the Nutrient Broth (Difco) and incubated at $37^{\circ} \mathrm{C}$ for $24 \mathrm{~h}$. The resulting cultures were inoculated onto the plates previously prepared with antibiotics by means of a multi-inoculation apparatus and were also incubated at $37{ }^{\circ} \mathrm{C}$ for $24 \mathrm{~h}$. Bacterial growth was recorded after this period. A resistance factor (RF) was obtained by dividing the Minimal Inhibitory Concentration (MIC) of the resistant E. coli HB101/pBR322 strain by the MIC of the sensitive E. coli HB101.

\section{Results and Discussion}

Characterization of complexes $\left[\mathrm{Pt}(\mathrm{Oxy}) \mathrm{Cl}_{2}\right] \cdot 2 \mathrm{H}_{2} \mathrm{O}(1)$, $\left[\mathrm{Pt}(\mathrm{Dox}) \mathrm{Cl}_{2}\right] \cdot 2 \mathrm{H}_{2} \mathrm{O}(2)$, and $\left[\mathrm{Pt}(\mathrm{Chl}) \mathrm{Cl}_{2}\right] \cdot 2 \mathrm{H}_{2} \mathrm{O}(\mathbf{3})$

Oxy, Dox, and Chl contain an identical 4-ring carbocyclic structure and substituent variations at carbons 5, 6, and 7 . The difference between oxytetracycline and tetracycline lies in the presence of an $\mathrm{OH}$ group at $\mathrm{C} 5$ in the first molecule. Doxycycline is also hydroxylated at C5 but it lacks the hydroxyl group at $\mathrm{C} 6$, though it has the same minimal formula as tetracycline. Chlortetracycline has one chlorine at C7.

The complexes were characterized by elemental analysis, conductivity measurements, vibrational spectroscopy and ${ }^{195} \mathrm{Pt} \mathrm{NMR}$. Interactions of $\mathrm{Pt}^{\mathrm{II}}$ ions with Dox were also studied in aqueous solution by ${ }^{1} \mathrm{H}$ NMR.

The results of the elemental analyses are in accordance with the proposed structures.

The molar conductivity values of $10^{-3} \mathrm{~mol} \mathrm{~L}^{-1}$ solutions for the three complexes were far below that of the 1:1 standard electrolyte indicating that they are not charged. 
The assignments of the infrared spectrum of the isolated complexes were made on the basis of a detailed study of IR and vibrational assignments for tetracycline and analogues made by Dziegielewski et al. ${ }^{16}$

The modifications observed in the complexes spectra compared those of the respective ligands are very similar and only the spectrum of the platinum complex of doxycycline, complex $\mathbf{2}$, will be discussed.

The IR spectrum of doxycycline shows characteristic absorptions at 3400 and $3200 \mathrm{~cm}^{-1}$, corresponding to $\mathrm{vOH}$ and $\mathrm{vNH}$, respectively. The first band is broader in the complex due to the presence of water.

The amide I band at $1670 \mathrm{~cm}^{-1}, v(\mathrm{C}=\mathrm{O})$, appears at $1661 \mathrm{~cm}^{-1}$ in the complex and decreases in intensity. Two very strong bands at 1618 and $1578 \mathrm{~cm}^{-1}$ are assigned to carbonyl stretching $v(\mathrm{C}=\mathrm{O})$ on rings $\mathrm{A}$ and $\mathrm{C}$, respectively. These bands appear for complex $\mathbf{2}$ at the same wavenumber, ruling out the participation of carbonyl oxygens in the coordination.

Two new absorptions at 307 and $316 \mathrm{~cm}^{-1}$ may be assigned to $v(\mathrm{Pt}-\mathrm{Cl})$ stretching in accordance to the cis geometry. ${ }^{11}$

These results suggest that the oxygen of the amide group is involved in the coordination sphere.

The interactions of doxycycline with $\mathrm{Pt}^{\mathrm{II}}$ ions were also studied in aqueous solution as a function of the $\mathrm{pH}$, by ${ }^{1} \mathrm{H}$ NMR spectroscopy.

Doxycycline possesses three ionizable protons: the first one in the $\mathrm{C}_{1}-\mathrm{C}_{3}$ tricarbonyl system in ring $\mathrm{A}$, the second in $\mathrm{C}_{10}$ and $\mathrm{C}_{12}$ ketophenolic system, and the third one in the $\mathrm{C}_{4}$ dimethylammonium group, with $\mathrm{pKa}$ values of 3.10 , 7.41, and 8.68, respectively. ${ }^{17}$ The presence of an $\mathrm{OH}$ group at $\mathrm{C} 5$ render its protons more acidic as compared to tetracycline, especially the one in the dimethylammonium group, whose pKa is 0.61 units lower.

The ${ }^{1} \mathrm{H}$ NMR spectra of Dox and Tc have already been assigned. ${ }^{17-23}$ Two regions in Dox ${ }^{1} \mathrm{H}$ NMR spectrum are of special interest for the attribution of metal coordination sites: the $\mathrm{D}$ ring aromatics and the dimethylamino, $\mathrm{C} 4$, $\mathrm{C} 4 \mathrm{a}$, and $\mathrm{C} 6$ protons on ring $\mathrm{A}$. These protons are not labile and their chemical shift, which is very sensitive to metal coordination, can be distinguished if the coordination occurs through $\mathrm{O} 10$ and $\mathrm{O} 12$ sites or through $\mathrm{A}$ ring sites. ${ }^{11,12}$ The $\mathrm{O}-\mathrm{H}$ protons and the A-ring amide protons cannot be observed because they are exchanged for deuterium.

Figure 1 presents a section of the ${ }^{1} \mathrm{H}$ NMR spectrum of a solution containing $5.0 \times 10^{-3} \mathrm{~mol} \mathrm{~L}^{-1}$ of Dox at $\mathrm{pH}$ 3.0, 5.0, 7.0, and 8.0. The resonance frequencies of the most affected protons, their assignments and the coupling constants are shown in Table 1. In the free ligand, the

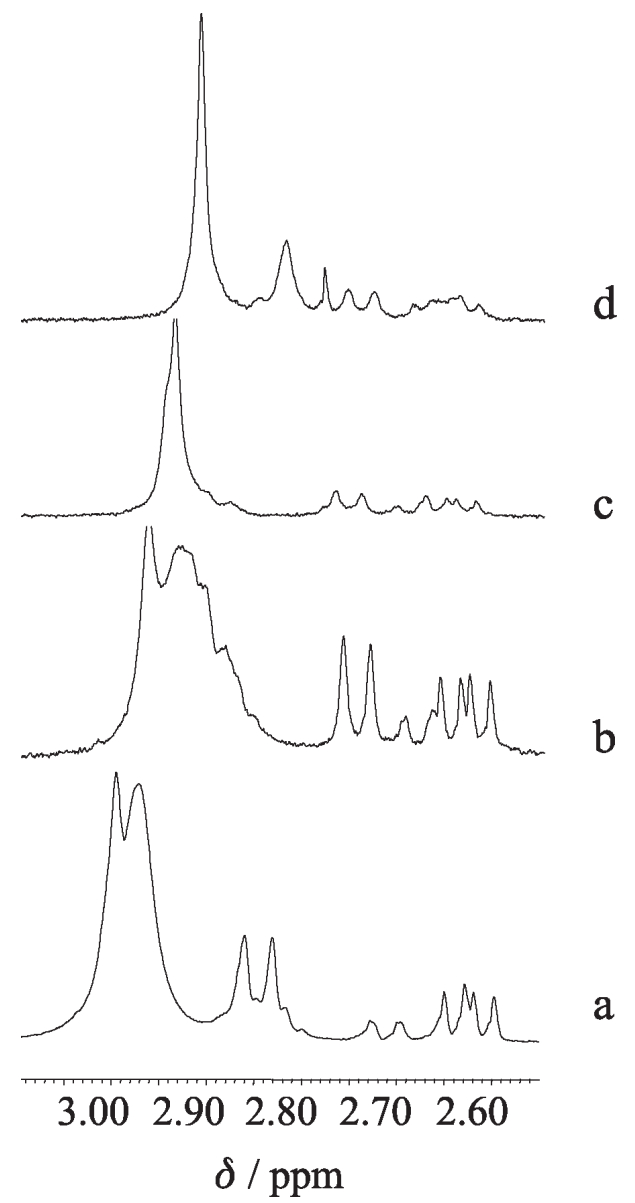

Figure 1. Sections of ${ }^{1} \mathrm{H}$ NMR spectra of solutions containing $5 \times 10^{-3}$ mol L ${ }^{-1}$ Dox at $\mathrm{pH}=3$ (a); 5 (b); 7 (c) and 8 (d).

protons of group $\mathrm{N}\left(\mathrm{CH}_{3}\right)_{2}$ give rise to two sets of resonances at $\mathrm{pH} 3$ (centered at $\delta 2.93$ ) and 5 (centered at $\delta$ 2.89). The presence of a proton in the $\mathrm{N}$-methyl group can prevent free rotation of the $\mathrm{CH}_{3}$ groups and render them non-equivalent.

Table 1. ${ }^{1} \mathrm{H}$ NMR data for doxycycline and complex 2 in $\mathrm{D}_{2} \mathrm{O}$ at different $\mathrm{pH}$. Coupling constants, $J(\mathrm{~Hz})$, are even in parenthesis, following chemical shifts

\begin{tabular}{|c|c|c|c|c|}
\hline & \multicolumn{4}{|c|}{$\mathrm{pH}$} \\
\hline & 3 & 5 & 7 & 8 \\
\hline $\begin{array}{l}\mathrm{H}_{4 \mathrm{a}} \\
\text { Dox }\end{array}$ & $\begin{array}{c}2.79 \\
(11.56)\end{array}$ & $\begin{array}{c}2.68 \\
(11.32)\end{array}$ & $\begin{array}{c}2.68 \\
(10.28)\end{array}$ & $\begin{array}{c}2.69 \\
(11.04)\end{array}$ \\
\hline $\begin{array}{l}\mathrm{H}_{4 \mathrm{a}} \\
\text { complex } \mathbf{2}\end{array}$ & $\begin{array}{c}2.81 \\
(11.15)\end{array}$ & $\begin{array}{c}2.70 \\
(11.60)\end{array}$ & $\begin{array}{c}2.69 \\
(10.76)\end{array}$ & - \\
\hline $\begin{array}{l}\mathrm{H}_{5 \mathrm{a}} \\
\text { Dox }\end{array}$ & $\begin{array}{c}2.57 \\
(8.52 ; 12.56)\end{array}$ & $\begin{array}{c}2.57 \\
(8.52 ; 12.56)\end{array}$ & $(8.80 ; 12.28)$ & - \\
\hline $\begin{array}{l}\mathrm{H}_{5 \mathrm{a}} \\
\text { complex } \mathbf{2}\end{array}$ & $\begin{array}{c}2.62 \\
(8.52 ; 12.32)\end{array}$ & $\begin{array}{c}2.59 \\
(8.86 ; 12.80)\end{array}$ & 2.60 & - \\
\hline $\begin{array}{l}\mathrm{N}\left(\mathrm{CH}_{3}\right)_{2} \\
\text { Dox }\end{array}$ & 2.93 & 2.89 & 2.87 & 2.86 \\
\hline $\begin{array}{l}\mathrm{N}\left(\mathrm{CH}_{3}\right)_{2} \\
\text { complex } 2\end{array}$ & 2.92 & 2.88 & 2.87 & 2.84 \\
\hline
\end{tabular}


By increasing the $\mathrm{pH}, \mathrm{N}$-methylenic protons at $\mathrm{C} 4$ are shielded, as it was expected due to the deprotonation in N4. Above $\mathrm{pH} 7$, these two sets of signals are no longer present and one observes a singlet at $\delta 2.87$. The presence of two sets of resonances is due to the fact that the methylenic protons are not chemical equivalent when the dimethylammonium group is protonated (pKa 8.68).

In Figure 2 the spectra of solutions containing 5.0 $\mathrm{x}$ $10^{-3} \mathrm{~mol} \mathrm{~L}^{-1}$ of doxycycline and $1.0 \times 10^{-2} \mathrm{~mol} \mathrm{~L}^{-1} \mathrm{Pt}^{\mathrm{II}}$ at $\mathrm{pH}$ 3.0, 5.0, 7.0, and 8.0 are shown. The main modification concerns the $\mathrm{N}$-methyl protons at ring A. In the presence of $\mathrm{Pt}^{\mathrm{II}}$ there are two sets of resonances related to $\mathrm{N}$-methyl protons from $\mathrm{pH} 3$ to 8 . At $\mathrm{pH} 7$ these protons appear as a singlet in the spectrum of Dox, and, in the presence of $\mathrm{Pt}^{\mathrm{II}}$ ions, they are splitted in two signals at $\delta 2.89$ and 2.86, since the methyl groups are no longer equivalent in the complex. Same effect is observed at low $\mathrm{pH}$ values, in which the dimethylammonium group, also at $\mathrm{C} 4$, is protonated. The presence of a proton at $\mathrm{N} 4$ or of a metal bound at ring A prevents free rotation of the two methyl groups. These results are indicative of complexation of the metal at ring A (see Figure 3).

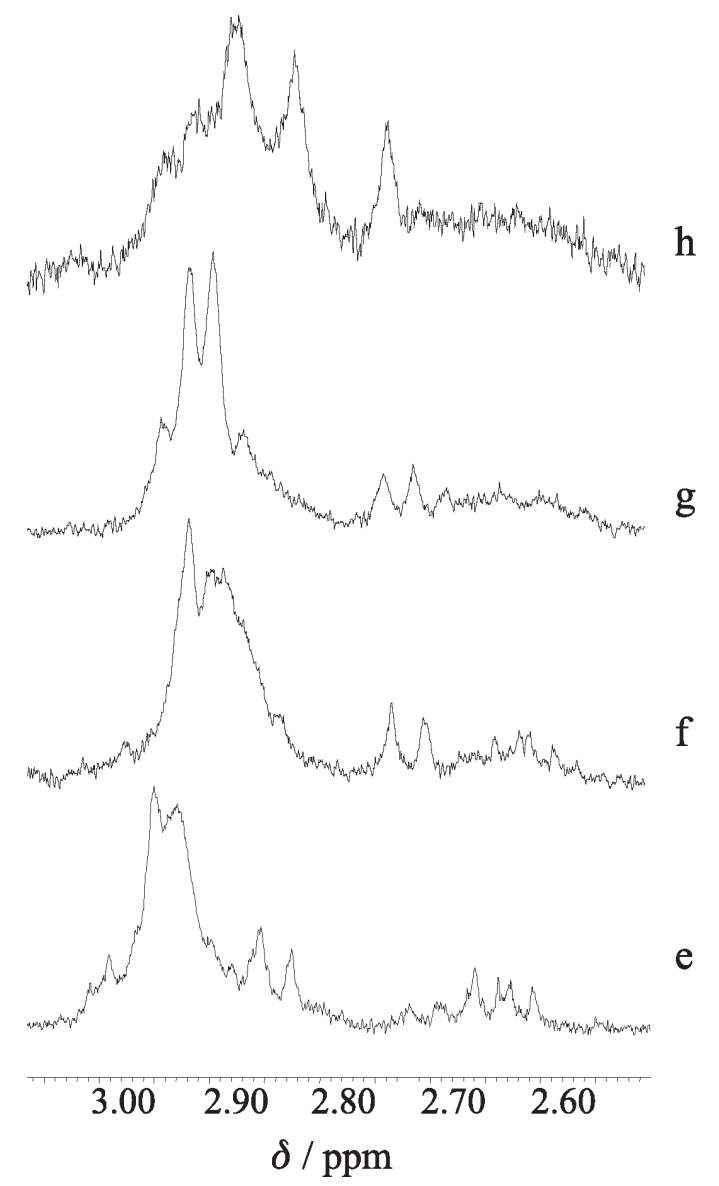

Figure 2. Sections of ${ }^{1} \mathrm{H}$ NMR spectra of solutions containing $5 \times 10^{-3}$ mol L-1 Dox and $1 \times 10^{-2} \mathrm{~mol} \mathrm{~L}^{-1} \mathrm{Pt}^{\mathrm{II}}$ at $\mathrm{pH}=3$ (a); 5 (b); 7 (c) and 8 (d).
A double doublet at $\delta 2.57$ was attributed to the $\mathrm{C} 5$ a proton. $\mathrm{C} 4 \mathrm{a}$ and $\mathrm{C} 5 \mathrm{a}$ are deshielded in the presence of $\mathrm{Pt}^{\mathrm{II}}$ ions.

The resonances related to the aromatic protons on the $\mathrm{D}$ ring are not affected by addition of the ion $\mathrm{Pt}^{\mathrm{II}}$. The involvement of the phenolic $\beta$-diketone system in the coordination sphere would lead to a chemical shift change of the D-ring protons, and this does not occur.

This pattern confirms that binding occurs at A-ring sites.

All the complexes were characterized by ${ }^{195} \mathrm{Pt}$ NMR spectroscopy. The purity of the complexes can be verified by this technique, since each species will generate a different signal. In the ${ }^{195} \mathrm{Pt}$ NMR spectra were observed signals at $\delta-1462.8,-1469.5$ and -1464.5 for complexes $\mathbf{1}, \mathbf{2}$, and $\mathbf{3}$, respectively. ${ }^{195} \mathrm{Pt}$ chemical shifts are sensitive to the nature of the ligands in the coordination sphere, and are a useful tool to predict the metal coordination sphere. The coordination sphere $\left(\mathrm{PtO}_{2} \mathrm{Cl}_{2}\right)$ is not very common and ${ }^{195} \mathrm{Pt}$ chemical shifts relative to it are scarce in the literature. For $\left[\mathrm{Pt}(\mathrm{Ox}) \mathrm{Cl}_{2}\right]^{2-}$ the reported $\delta(\mathrm{Pt})$ is -1005 and for $\left[\mathrm{Pt}(2-\text {-methymalonato }) \mathrm{Cl}_{2}\right]^{2-}-995 .{ }^{24}$ Due to the low solubility of the compounds in water, ${ }^{195} \mathrm{Pt}$ NMR spectra were measured in a $1 \times 10^{-2} \mathrm{~mol} \mathrm{~L}^{-1}$ solution in dimethylformamide (DMF). It is possible that the species present in DMF and in water are not the same. In aqueous solution, at neutral $\mathrm{pH}$, Dox is present as a zwitterion, in which the dimmethylammonium group is protonated and the oxygen at $\mathrm{C} 3$ deprotonated. In lower dielectric media, the more stable species is a neutral tautomer, in which the proton of the dimethylammonium group is transferred to the oxygen at carbon 3 . In the neutral tautomer the most basic site is the amino nitrogen at $\mathrm{C} 4$. It is possible that in DMF, $\mathrm{Pt}^{\mathrm{II}}$ ions are coordinated to the nitrogen of the dimethylamino group, to the oxygen at $\mathrm{C} 3$ and to two chlorides. Quite recently, dos Santos et al. ${ }^{25}$ reported a theoretical analysis for a complex of $\mathrm{Pt}^{\mathrm{II}}$ with anhydrotetracycline. The global minimum in the gas phase corresponded to the coordination of $\mathrm{P}^{\mathrm{II}}$ to the $\mathrm{N} 4$ and $\mathrm{O} 3$, which is the mode we propose to be present in a lower dielectric media. Calculations taking into account the solvation energy pointed to two different coordination sites: $\mathrm{O} 3$ and amide oxygen or amide oxygen and $\mathrm{O} 1$. The authors compared their calculated ${ }^{1} \mathrm{H}$ NMR spectrum to our previous experimental results for the $\mathrm{Pt}^{\mathrm{II}}$ complex of tetracycline and concluded that in aqueous solution $\mathrm{Pt}^{\mathrm{II}}$ ion might be bound to $\mathrm{O} 3$ and the amide oxygen. ${ }^{25}$

The proposed structures for complexes 1, 2, and $\mathbf{3}$ are presented in Figure 3. The same coordination mode has been observed for an $\mathrm{HgCl}_{2}$ complex of oxytetracycline, which had its crystal structure determined. ${ }^{26}$

Other coordination possibilities would involve the O12O10 system. However, the participation of the phenolic 


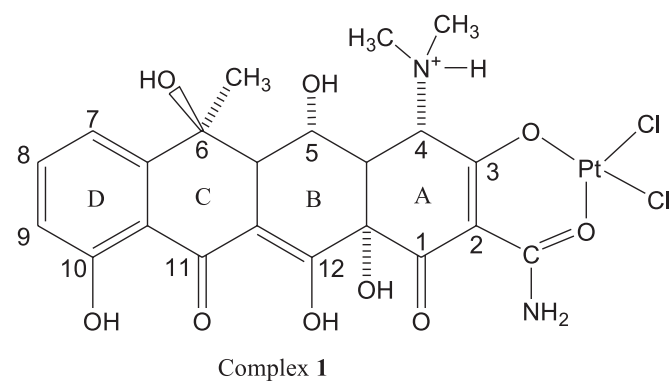<smiles>C[C@H]1c2cccc(O)c2C(=O)C2=C(O)[C@]3(O)C(=O)C4=C(O[P](Cl)(Cl)OC4N)[C@H]([N+](C)(C)C)[C@H]3[C@@H](O)C21</smiles>

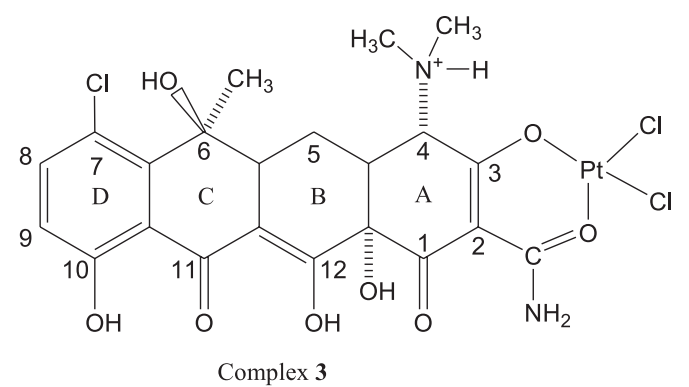

Figure 3. Proposed structures for platinum complexes 1, 2 and $\mathbf{3 .}$

$\beta$-diketone system in the coordination sphere would lead to a frequency shift of the D-ring protons, and this does not occur. Moreover, in the IR spectrum of the complex, the $\mathrm{vC}=\mathrm{O}$ of the carbonyl at $\mathrm{C} 11$ appears at the same wavenumber as the ligand, $1578 \mathrm{~cm}^{-1}$. Therefore, we ruled out an involvement of these sites in platinum coordination.

\section{Antimicrobial activity}

The minimal inhibitory concentrations (MIC) of the ligands and those of their $\mathrm{Pt}^{\mathrm{II}}$ compounds were investigated in two sensitive strains (E. coli HB 101 and E. coli
ATCC 25922) and in a resistant one (E. coli HB101/ pBR322). The resistant strain E. coli HB101/pBR322 express Tet A(B) protein encoded on the pBR3222 plasmid. A resistance factor (RF) was calculated by dividing the MIC of E. coli HB101/pBR322 by that of the parental sensitive strain $E$. coli HB 101. Neither the solvent nor the platinum salt used in the synthesis affected the bacterial growth in the concentrations used.

As one can see in Table 2, the RF of Oxy is twofold higher than that of Dox and Chl. The RF of complexes 2 and $\mathbf{3}$ is 4 times higher than that of complex 1. i.e., the resistant strain exhibits the highest $\mathrm{RF}$ to Oxy and its $\mathrm{Pt}^{\mathrm{II}}$ complex.

$\mathrm{Pt}^{\mathrm{II}}$ coordination to $\mathrm{Chl}$ and to Oxy does not improve their activity against the E. coli HB101/pBR322 strain while complex $\mathbf{2}$ is twice as potent as free Dox (Table 2). Previously, we had observed that a $\mathrm{Pd}^{\mathrm{II}}$ complex of $\mathrm{Chl}$ had the same activity as the free ligand whereas $\mathrm{Pd}^{\mathrm{II}}$ complexes of Tc and Dox were more potent than the respective ligands. ${ }^{12}$ The different effect observed for the complexes of Chl and Oxy as compared to that of Dox is a puzzling question as their structures differ only in substituents at carbons 5, 6, and 7 .

Bioavailability of tetracyclines is affected by metal coordination and the different substituents present in this series affect the lipophilicity of the antibiotics. ${ }^{27}$ In order to seek a structure/activity relation, we have investigated the lipophilicity of $\mathbf{1}, \mathbf{2}$, and, $\mathbf{3}$. Partition coefficient in octanol/water is often used to assess the lipophilic character of drugs: hydrophobic compounds will have a high $P$ value whereas hydrophilic compounds will have a low $P$ value. In Table 2, one can observe that as $P$ increases MIC values decrease in the resistant strain E. coli HB101/ pBR322. This correlation between antimicrobial activity and partition coefficients suggest that increasing complexes hydrophobicity causes an increase in the antimicrobial activity in the resistant strain.

The hydrophobic character of a drug is crucial to how easily it crosses cell membranes and may also be important in receptor interactions. The resistance conferred by the

Table 2. MIC of free tetracyclines and their platinum(II) compounds ${ }^{\mathrm{a}}$

\begin{tabular}{|c|c|c|c|c|c|c|}
\hline \multirow[b]{2}{*}{ Bacterial strains } & \multicolumn{5}{|c|}{$\mathrm{MIC} /(\mu \mathrm{M})$} & \multirow[b]{2}{*}{3} \\
\hline & Oxy & 1 & Dox & 2 & Chl & \\
\hline ATCC 25922 & 8.32 & 8.32 & 8.32 & 4.16 & 2.08 & 2.08 \\
\hline НВ 101 & 4.16 & 4.16 & 2.08 & 2.08 & 2.08 & 4.16 \\
\hline HB101/ pBR322 & 266.20 & 266.20 & 66.50 & 33.30 & 66.50 & 66.50 \\
\hline $\mathrm{RF}$ & 63.99 & 63.99 & 31.97 & 16.01 & 31.97 & 15.99 \\
\hline$P^{\mathrm{b}}$ & - & 0.01 & - & 1.76 & - & 0.68 \\
\hline
\end{tabular}

a MIC is the minimal drug concentration required to inhibit bacterial growth. RF is the MIC of HB101/ pBR322 divided by the MIC of HB 101. Number of essays $=4$. ${ }^{\mathrm{b}} \mathrm{P}$ is the total platinum in $n$-octanol divided by total platinum in the aqueous layer. 
presence of Tet $A(B)$ is due to a decrease of the intracellular drug concentration to a level inferior to the one necessary for the activity. A possible explanation for the antimicrobial activity of these $\mathrm{Pt}^{\mathrm{II}}$ compounds is that by increasing their lipophilicity the intracellular drug concentration inside resistant bacterial cell increases.

The most important result is that $\mathrm{Pt}^{\mathrm{II}}$ coordination to Dox improves the antibiotic activity in the resistant strain. In a previous work, we have found that a platinum(II) complex of tetracycline $(\mathrm{Tc}),\left[\mathrm{Pt}(\mathrm{Tc}) \mathrm{Cl}_{2}\right]$, was six times as potent as $\mathrm{Tc}$ in inhibiting the bacterial growth of the strain resistant to tetracycline. ${ }^{11}$ The mechanism by which complex $\mathbf{2}$ can overcome tetracycline resistance is still unclear. We can speculate that either it does not bind to the repressor molecule and thus $\operatorname{Tet} \mathrm{A}(\mathrm{B})$ is not expressed in its presence, or that even if $\operatorname{Tet} A(B)$ is expressed it cannot effectively transport the platinum complex out of the bacterial cell. Finding agents that are not recognized by the resistance mechanisms is very important because the emergence of bacterial resistance is the main obstacle for tetracycline derivatives use in the treatment of bacterial infections.

\section{Supplementary Information}

${ }^{195} \mathrm{Pt}$ NMR spectra of compounds $\mathbf{1}, \mathbf{2}$, and $\mathbf{3}$ are available free of charge at http://jbcs.sbq.org.br, as a PDF file.

\section{Acknowledgments}

This work was supported by grants of CNPq (Conselho Nacional de Desenvolvimento Científico e Tecnológico, Brazil) and FAPEMIG (Fundação de Amparo à Pesquisa de Minas Gerais, Brazil).

\section{References}

1. Chopra, I.; Hawkey, P. M.; Hinton, M. J.; Antimicrob. Chemother. 1992, 29, 245.

2. Chartone-Souza, E.; Ciencia Hoy (in Spanish) 1999, 9, 30.

3. Lambs, L.; Brion, M.; Berthon, G.; Inorg. Chim. Acta 1983, 106, 151.

4. Brion, M.; Berthon, G.; Fourtellan, J. B.; Inorg. Chim. Acta 1981, 55, 47.

5. Salyers, A. A.; Speer, B. S.; Shoemaker, N. B.; Mol. Microbiol.1990, 4, 151.
6. Davies, J.; Science 1994, 264, 375.

7. Nikaido, H.; Science 1994, 264, 382.

8. Saenger, W; Orth, P. K. C.; Hillen, W.; Hinrichs, W.; Angew. Chem. Int. Ed. 2000, 39, 2042.

9. McMurry, L.; Petrucci, R. E.; Levy, S. B.; Proc. Natl. Acad. Sci. USA 1980, 77, 3974.

10. Speer, B. S.; Shoemaker, N. B.; Salyers, A. A.; Clin. Microbiol. Rev. 1992, 5, 387.

11. Chartone-Souza, E.; Loyola, T. L.; Bucciarelli-Rodriguez, M.; Menezes, M. A.; Rey, N. A.; Pereira-Maia, E. C.; J. Inorg. Biochem. 2005, 99, 1001.

12. Guerra, W.; Azevedo, E. A.; Monteiro, A. R. S.; ChartoneSouza, E.; Nascimento, A. M. A.; Bucciarelli-Rodriguez, M.; Fontes, A. P. S.; Le Moyec, L.; Pereira-Maia, E. C.; J. Inorg. Biochem. 2005, 99, 2348.

13. Robillard, M. S.; Galanski, M.; Zimmermann, W.; Keppler, K. B.; Reedijk, J.; J. Inorg. Biochem. 2002, 88, 254.

14. Lacks, S.; Greenberg, B.; J. Mol. Biol. 1977, 114, 153.

15. Rodriguez, R. L.; Tait, R.; Shine, J.; Bolivar, F.; Heyneker, H.; Betlach, M.; Boyer, H. W.; In Molecular Cloning of Recombinant DNA; Scott, W. A.; Werner, R., eds.; Winter Symposia: Miami, 1977, 13, 73.

16. Dziegielewski J.; Hanuza J.; Jezowska-Trzebiatowska, B.; Bull. Acad. Pol. Sci., Ser. Sci. Chim. 1976, 24, 307.

17. Lambs,L.; Decock-Le Révérend, B.; Kozlowski, H.; Berthon, G.; Inorg. Chem. 1988, 273001.

18. Casy, A. F.; Yasin, A.; J. Pharm. Biomed. Anal. 1983, 1, 281.

19. Casy, A. F.; Yasin, A.; Magn. Res. Chem. 1985, 23, 767.

20. Willianson, D. E.; Everett, G. W.; J. Am. Chem. Soc. 1975, 97 , 2397.

21. Asleson, G. L.; Stoel, L. J.; Newton, E. C.; Frank, C. W.; J. Pharm. Sci. 1974, 63, 1144.

22. Rigler, N. E.; Bag, S. P.; Leyden, E. D.; Sudmeier, J. L.; Reilley, C. M; Anal. Chem. 1965, 37, 872.

23. Yang, W.; Moore, K. I.; Koteva, P. K.; Barei, C. D.; Hurghes, W. D.; Wrigth, D. G.; J. Biol. Chem. 2004, 279, 52346.

24. Dunham,S. O.; Larsen, R. D.; Abbott,E. H.; Inorg. Chem. 1991, 30, 4328.

25. Dos Santos, H. F.; Marcial, B. L.; De Miranda, C. F.; Costa, L. A. S.; De Almeida, W. B.; J. Inorg. Biochem. 2006, 100, 1594.

26. Jogun, K. H.; Stezowski, J. J.; J. Chem. Soc. 1976, 98, 6018.

27. Brown, J. R.; Ireland, D. S.; Adv. Pharmacol. Chemother. 1978 , 15,161
Received: June 9, 2006

Published on the web: December 1, 2006 
Three new Complexes of Platinum(II) with Doxycycline, Oxytetracycline and Chlortetracycline and their Antimicrobial Activity

\section{Wendell Guerra, ${ }^{a}$ Iara R. Silva, ${ }^{a}$ Elaine A. Azevedo, ${ }^{a}$ Ana R. de S. Monteiro, ${ }^{b}$ Mônica Bucciarelli-} Rodriguez, ${ }^{b}$ Edmar Chartone-Souza, ${ }^{b}$ Josianne N. Silveira, ${ }^{c}$ Ana P. S. Fontes ${ }^{d}$ and Elene C. Pereira-Maia ${ }^{*, a}$

${ }^{a}$ Departamento de Química, ICEx, ${ }^{b}$ Departamento de Biologia Geral, ICB and ${ }^{c}$ Departamento de Análises Clínicas e Toxicológicas, FF,

Universidade Federal de Minas Gerais, 31270-901 Belo Horizonte - MG, Brazil

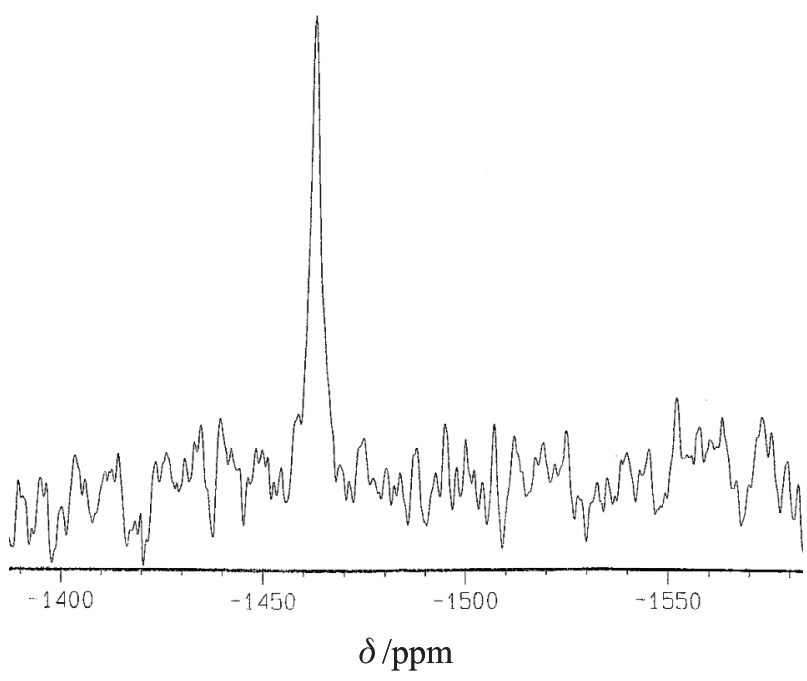

Figure S1. ${ }^{195} \mathrm{Pt}$ NMR spectra of complex $\mathbf{1}$.

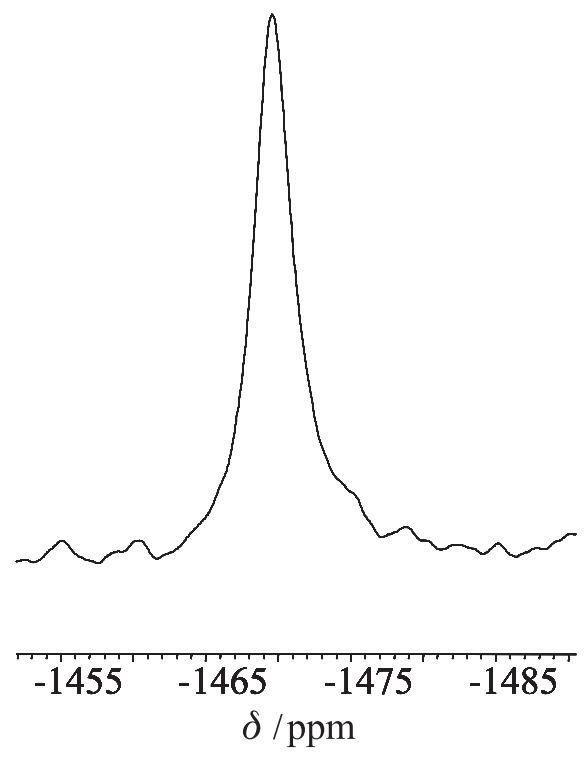

Figure S2. ${ }^{195} \mathrm{Pt}$ NMR spectra of complex 2.

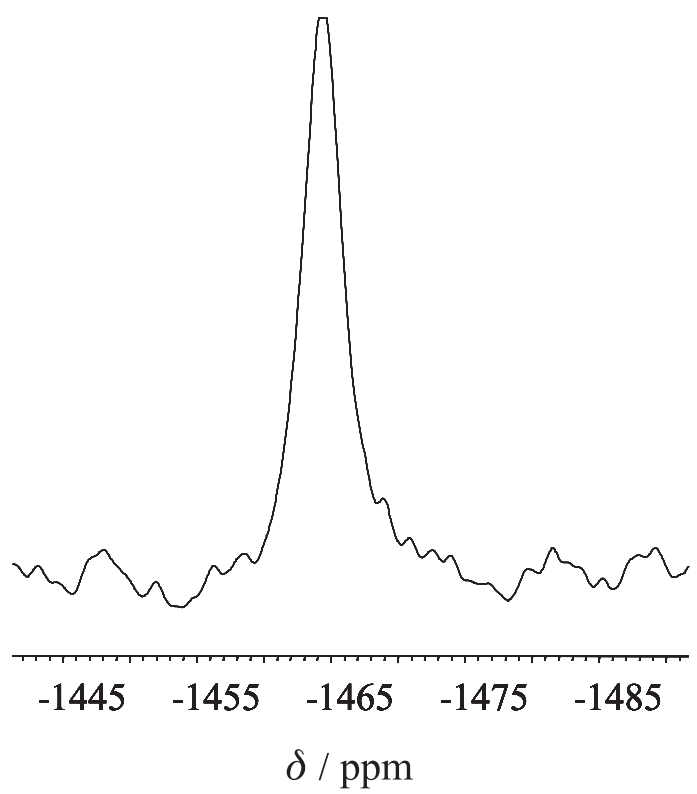

Figure S3. ${ }^{195} \mathrm{Pt}$ NMR spectra of complex 3 .

*e-mail: elene@qui.ufmg.br 